\title{
POTENSI PENDAPATAN ASLI DAERAH DALAM RANGKA PELAKSANAAN OTONOMI DAERAH DI KABUPATEN INDRAMAYU*
}

\author{
Irfan Khairul Umam ${ }^{1}$ \\ Permalink: https://www.academia.edu/9999191
}

\begin{abstract}
Local Revenue Potential in the Context of Regional Autonomy in Indramayu. Abstract: Demands to increase revenue (PAD) greater, together with the increasing number of delegation of authority from the central government to local governments. Financial transfers made by the central government to local governments through equalization funds are relatively adequate for the implementation of regional autonomy, nevertheless required local governments to explore more creative fullest potential local funding sources, as this greatly helps to increase accountability and flexibility in the use of Budgets. The results showed that the acceptance of the PAD consists of local taxes, levies, wealth management outcomes separated areas as well as other PAD legitimate and execution of the collection is done by the work unit or related agencies.
\end{abstract}

Keywords: PAD, Autonomy, Indramayu district

\begin{abstract}
Abstrak: Potensi Pendapatan Asli Daerah Dalam Rangka Pelaksanaan Otonomi Daerah di Kabupaten Indramayu. Tuntutan untuk meningkatkan pendapatan asli daerah (PAD) semakin besar, berbarengan dengan semakin banyaknya pelimpahan kewenangan dari pemerintah pusat kepada pemerintah daerah. Transfer keuangan yang dilakukan oleh pemerintah pusat kepada pemerintah daerah melalui dana perimbangan jumlahnya relatif memadai dalam rangka pelaksanaan otonomi daerah, walaupun begitu pemerintah daerah diharuskan lebih kreatif untuk menggali secara maksimal sumber pembiayaan daerah yang potensial, karena hal ini sangat membantu meningkatkan akuntabilitas dan keleluasaan dalam penggunaan APBD. Hasil penelitian menunjukkan bahwa penerimaan PAD terdiri dari pajak daerah, retribusi daerah, hasil pengelolaan kekayaan daerah yang dipisahkan serta lain-lain PAD yang sah dan pelaksanaan pemungutannya dilakukan oleh unit kerja atau dinas-dinas terkait.
\end{abstract}

Kata Kunci: PAD, Otonomi Daerah, Kabupaten Indramayu

\footnotetext{
Diterima tanggal naskah diterima: 10 November 2014, direvisi: 22 November 2014, disetujui untuk terbit: 26 November 2014.

${ }^{1}$ Fakultas Syariah dan Hukum UIN Syarif Hidayatullah Jakarta. Jl. Ir. H. Juanda No. 95 Ciputat Jakarta. E-mail: hk_irfan@yahoo.co.id
} 


\section{Pendahuluan}

Pada saat pemerintahan Orde Baru sistem politik dan ekonomi yang dibangun sentralistik, daerah tidak dapat berkembang secara optimal sehingga mengakibatkan perkembangan daerah tidak berjalan secara maksimal disamping itu semua kebijakan tentang daerah selalu diputuskan oleh pemerintah pusat, daerah tidak memiliki keleluasaan untuk mengembangkan potensi daerahnya padahal hal ini sangat dibutuhkan oleh daerah dalam menjalankan roda pemerintahannya, sehingga mengakibatkan daerah sangat tergantung bantuan dari pemerintah pusat. Padahal dalam pengukuran terhadap keberhasilan suatu daerah dalam melaksanakan asas desentralisasi, maka salah satu kriteria yang penting untuk mengetahui secara nyata kemampuan suatu daerah dalam mengatur dan mengurus rumah tangganya. ${ }^{2}$ Artinya semakin banyak pendapatan yang diperoleh oleh pemerintah daerah yang berasal dari berbagai sumber seperti: pendapatan asli daerah yang terdiri dari hasil pajak daerah, retribusi daerah, hasil pengelolaan kekayaan daerah yang dipisahkan dan lain-lain pendapatan asli daerah yang sah, dana perimbangan, lain-lain pendapatan daerah yang sah oleh pemerintah daerah maka semakin efektiflah jalannya roda pemerintahan daerah.

Pemerintah pusat pada saat itu juga mengatur secara terperinci mengenai kewenangan pemerintah daerah dan cenderung diseragamkan secara nasional sehingga daerah tidak bisa berbuat lebih banyak untuk mengoptimalkan jalannya roda pemerintahan di daerahnya. Tidak hanya itu saja pemerintah pusat pun mengatur organ-organ suprastruktur politik daerah secara terpusat dan cenderung diseragamkan tanpa mempertimbangkan keberagaman sistem politik yang ada di daerah, padahal kita tahu bahwasanya sistem ini telah ada sebelum bangsa Indonesia ini merdeka. Keadaan tersebut mengakibatkan negara dianggap gagal menciptakan suatu sistem tata pemerintahan yang baik dengan wewenang desentralisasi. Hal itu menimbulkan keyakinan baru bagi masyarakat di daerah bahwa pusat bukan hanya mengeksploitasi mereka tetapi juga mengambil alih hak-hak mereka untuk mendapat pelayanan manusiawi oleh pemerintahan yang baik hingga bermula pada penguatan kembali keinginan untuk membentuk negara federal. ${ }^{3}$

Negara kita adalah Negara Kesatuan Republik Indonesia yang tercantum dalam Undang-Undang Dasar Negara Republik Indonesia Tahun 1945, yang terbentuk dari berbagai suku-suku dan berbagai macam adat istiadat dan keanekaragaman lainnya. Para perumus Undang-Undang Dasar Negara Republik Indonesia Tahun 1945 dengan seksama mempertimbangkan keanekaragaman tersebut dengan memasukkan aturan mengenai pemerintahan daerah ke dalam konstitusi negara Indonesia, dengan tidak menyeragamkan terhadap semua daerah. Dalam Pasal 18 Undang-Undang Dasar Negara Republik Indonesia Tahun 1945 (sebelum amandemen) disebutkan bahwa:

${ }^{2}$ Adrian Sutedi, Implikasi Hukum Atas Sumber Pembiayaan Daerah dalam Kerangka Otonomi Daerah, (Jakarta: Sinar Grafika, 2009), h.18

${ }^{3}$ Ni'matul Huda, Otonomi Daerah "Filosofi, Sejarah Perkembangan dan Problematika", (Yogyakarta: Pustaka Pelajar, 2001), h.61. 
Salam; Jurnal Filsafat dan Budaya Hukum - 331

"Pembagian daerah Indonesia atas daerah besar dan kecil, dengan bentuk susunan pemerintahannya ditetapkan dengan undang-undang, dengan memandang dan mengingat dasar permusyawaratan dalam sistem pemerintahan negara, dan hak-hak asal-usul dalam daerah-daerah yang bersifat istimewa".

Adapun penjelasannya sebagai berikut :

"Oleh karena negara Indonesia itu suatu eenheid-staat, maka Indonesia tak akan mempunyai daerah di dalam lingkungannya yang bersifat "staat" juga. Daerah Indonesia akan dibagi pula dalam daerah yang lebih kecil. Daerah-daerah itu bersifat otonom (Streek dan locale rechtgemeenschappen) atau bersifat daerah administrasi belaka, semuanya menurut aturan yang ditetapkan dengan undang-undang. Di daerah-daerah yang bersifat otonom akan diadakan badan perwakilan daerah, oleh karena di daerahpun pemerintah akan bersedia atas dasar permusyawaratan."

Pada pemerintahan Orde Reformasi aturan mengenai pemerintahan daerah terdapat dalam Ketetapan Majelis Permusyawaratan Rakyat Republik Indonesia Nomor XV/MPR/1998, lebih lengkapnya sebagai berikut:

Penyelenggaraan otonomi daerah dengan memberikan kewenangan yang luas, nyata dan bertanggung jawab di daerah secara proporsional diwujudkan dengan pengaturan, pembagian dan pemanfaatan sumber daya nasional yang berkeadilan serta perimbangan keuangan pusat dan daerah. ${ }^{6}$

Adapun mengenai peraturan perundang-undangan yang mengatur Pemerintahan Daerah adalah sebagai berikut : Undang-Undang Nomor 5 Tahun 1974 Tentang Pokok-Pokok Pemerintahan Daerah, Undang-Undang Nomor 22 Tahun 1999 Tentang Pemerintahan Daerah, Undang-Undang Nomor 32 Tahun 2004 Tentang Pemerintahan Daerah.

Dalam penelitian ini penulis merujuk pada ketentuan Undang-Undang Nomor 32 Tahun 2004 terutama Pasal 157 tentang sumber pendapatan daerah namun mengkhususkan membahas tentang pendapatan asli daerah yang merupakan bagian dari sumber pendapatan daerah. ${ }^{7}$

Adapun untuk mendukung penyelenggaraan otonomi daerah diperlukan kewenangan yang luas, nyata dan bertanggung jawab di daerah secara proporsional yang diwujudkan dengan pengaturan, pembagian dan pemanfaatan sumber daya nasional yang berkeadilan, serta pembagian keuangan pemerintah pusat dan daerah. Sumber pembiayaan pemerintah daerah dalam rangka perimbangan keuangan pemerintah pusat dan daerah dilaksanakan atas dasar

\footnotetext{
${ }^{4}$ Pasal 18 Undang-Undang Dasar Negara Republik Indonesia Tahun 1945

${ }_{6}^{5}$ Penjelasan Pasal 18 Undang-Undang Dasar Negara Republik Indonesia Tahun 1945

${ }^{6}$ Adrian Sutedi, Implikasi Hukum Atas Sumber Pembiayaan Daerah dalam Kerangka Otonomi Daerah, h.16.

${ }^{7}$ Pasal 157 Undang-Undang Nomor 32 Tahun 2004 Tentang Pemerintahan Daerah
} 
desentralisasi, dekonsentrasi dan tugas pembantuan (medebewind). ${ }^{8}$ Hal ini sebagaimana asas-asas penyelenggara pemerintahan menurut Undang-Undang Nomor 32 Tahun 2004 Tentang Pemerintahan Daerah.

Pengaturan sumber daya alam yang dilakukan oleh pemerintah pusat adalah menempatkan posisinya sebagai regulator yang wajar dan adil. Pada dasarnya pembagiannya itu dilakukan secara seimbang, hal ini dilakukan agar pemerintah pusat dapat memperhatikan kepentingan yang luas demi terciptanya pembangunan yang adil dan merata namun dengan tetap memperhatikan daerah tersebut agar tidak terjadi kecemburuan antara pemerintah pusat dan pemerintah daerah. Konstruksi otonomi daerah tetap mengedepankan hakikat pembagian sumber daya alam yang wajar dan adil agar pelaksanaan otonomi daerah dapat direalisasikan sebagaimana mestinya.?

Salah satu ukuran keberhasilan suatu daerah otonom dapat dilihat dari kemampuan dalam pengelolaan keuangan daerah. Pengelolaan keuangan daerah yang baik akan bermuara pada peningkatan pendapatan asli daerah dan meningkatnya usaha-usaha pembangunan. Dalam hal ini yang dimaksud keuangan daerah adalah semua hak dan kewajiban daerah yang dapat dinilai dengan uang dan segala sesuatu berupa uang dan barang yang dapat dijadikan milik daerah yang berhubungan dengan pelaksanaan hak dan kewajiban tersebut. ${ }^{10}$

Tuntutan untuk meningkatkan pendapatan asli daerah semakin besar beriringan dengan semakin banyaknya pelimpahan dari kewenangan pemerintahan pusat kepada pemerintahan daerah dibarengi dengan pengalihan personil, peralatan, pembiayaan dan dokumentasi ke pemerintah daerah dalam jumlah yang sangat besar. Transfer keuangan yang dilakukan oleh pemerintah pusat kepada pemerintah daerah melalui dana perimbangan jumlahnya relatif memadai dalam rangka pelaksanaan otonomi daerah, walaupun begitu pemerintah daerah diharuskan lebih kreatif untuk menggali secara maksimal sumber-sumber pembiayaan daerah yang potensial dalam meningkatkan pendapatan asli daerahnya karena hal ini sangat membantu dalam meningkatkan akuntabilitas dan keleluasan dalam penggunaan anggaran pendapatan dan belanja daerahnya. Visi ekonomi dari otonomi daerah adalah bahwa pemerintah daerah diharuskan mampu menjamin lancarnya kebijakan ekonomi nasional sekaligus mampu mengembangkan perekonomian sesuai dengan potensi yang dimiliki oleh daerah. ${ }^{11}$

${ }^{8}$ HAW. Widjaja, Penyelenggaraan Otonomi Daerah di Indonesia, (Jakarta: PT Raja Grafindo Persada, 2005), h.26.

${ }_{9}$ Hari Sabarno, Memandu Otonomi Daerah Menjaga Kesatuan Bangsa, (Jakarta: Sinar Grafika, 2008), h.12.

${ }^{10}$ Rozali Abdullah, Pelaksanaan Otonomi Luas dengan Pemilihan Kepala Daerah secara langsung, (Jakarta: PT. Raja Grafindo Persada, 2005), h.143.

${ }_{11}$ Agus, Pramusinto dan Erwan Agus Purwanto, Reformasi Birokrasi, Kepemimpinan dan Pelayanan Publik: Kajian tentang Pelaksanaan Otonomi Daerah di Indonesia, (Yogyakarta: Gava Media, 2009), h.398. 
Salam; Jurnal Filsafat dan Budaya Hukum - 333

Dengan memperhatikan latar belakang masalah diatas, penulis sangat tertarik untuk melakukan penelitian tentang: "Potensi Pendapatan Asli Daerah dalam Rangka Pelaksanaan Otonomi Daerah di Kabupaten Indramayu.”

\section{Pengertian Otonomi Daerah}

Otonomi berasal dari bahasa Latin Autos dan Nomos. Autos berarti sendiri sedangkan Nomos berarti aturan. ${ }^{12}$ Menurut Sugeng Istanto yang dikutip oleh Edi Toet Hendratno dalam bukunya yang berjudul Negara Kesatuan, Desentralisasi dan Federalisme, otonomi daerah adalah sebagai hak atau wewenang untuk mengatur dan mengurus rumah tangga daerah. ${ }^{13}$

Menurut Bagir Manan, otonomi daerah mempunyai dua arti: pertama, dalam arti formal otonomi daerah diperlukan dalam rangka memperluas partisipasi masyarakat dalam pemerintahan. Kedua, dalam arti materiil otonomi daerah mengadung makna sebagai usaha mewujudkan kesejahteraan dan sistem pemencaran kekuasaan menurut dasar negara berdasarkan atas hukum. ${ }^{14}$

Menurut Pasal 1 ayat (5) Undang-Undang Nomor 32 Tahun 2004. Otonomi Daerah adalah: hak, wewenang dan kewajiban daerah otonom untuk mengatur dan mengurus sendiri urusan pemerintahan dan kepentingan masyarakat setempat sesuai dengan peraturan perundang-undangan. ${ }^{15}$

\section{Prinsip-Prinsip Otonomi Daerah}

Menurut Agus Salim Andi Gadjong, ada 3 hal dalam prinsip otonomi daerah, yaitu: 1). Harus serasi dengan pembinaan politik dan kesatuan bangsa; 2). Dapat menjamin hubungan yang serasi antara pemerintah pusat dengan daerah atas dasar keutuhan negara kesatuan; 3). Harus dapat menjamin perkembangan dan pembangunan daerah. ${ }^{16}$ Sedangkan menurut Hedl yang dikutip oleh Ni'matul Huda, prinsip otonomi menggambarkan secara esensial dua gagasan dasar; 1). Ide bahwa rakyat seharusnya berhak menentukan sendiri nasibnya; 2). Gagasan tentang pemerintahan demokratis harus dibatasi sebagai pemerintah yang menegaskan struktur terbatas kekuasaan secara legal. ${ }^{17}$

Menurut Undang-Undang Nomor 32 Tahun 2004 Tentang Pemerintahan Daerah, mengisyaratkan bahwa penyelenggaraan otonomi daerah berdasarkan pada prinsip otonomi seluas-luasnya. ${ }^{18}$ Artinya daerah diberikan

12 Abdurrahman, Beberapa Pemikiran Tentang Otonomi Daerah, Cetakan pertama, (Jakarta: Media Sarana Presss, 1987), h.9.

13 Edie Toet Hendratno, Negara Kesatuan, Desentralisasi dan Federalisme, Cet I, (Yogyakarta: Graha Ilmu, 2009), h.63-64.

${ }^{14}$ Bagir Manan, Menyongsong Fajar Otonomi Daerah, Cetakan pertama, (Yogyakarta: Pusat Studi Hukum Fakultas Hukum UII, 2005), h.59

Daerah

${ }^{15}$ Pasal 1 ayat (5) Undang-Undang Nomor 32 Tahun 2004 Tentang Pemerintahan

${ }^{16}$ Agus Salim Andi Gadjong, Pemerintahan Daerah “Kajian Politik dan Hukum”, (Bogor: Ghalia Indonesia, 2007), h.110.

${ }^{17}$ Ni'matul Huda, Otonomi Daerah "Filosofi, Sejarah Perkembangan dan Problematika", h.118.


Ancaman Disintegrasi, (Jayapura: Universitas Cendrawasih), h.73. 
kewenangan mengurus dan mengatur rumah tangganya. Adapun kewenangannya itu antara lain: membuat kebijakan daerah untuk memberi pelayanan, peningkatan peran serta, prakarsa dan pemberdayaan masyarakat yang bertujuan untuk mensejahterakan rakyatnya.

Prinsip otonomi seluas-luasnya yang diisyaratkan dalam UndangUndang Nomor 32 Tahun 2004 itu, bukan berarti bebas tanpa batas namun berdasarkan pada prinsip bertanggung jawab dan diiringi juga dengan prinsip otonomi yang nyata. Prinsip otonomi nyata adalah suatu prinsip yang bermakna bahwa untuk menangani urusan pemerintahan dilaksanakan berdasarkan tugas, wewenang dan kewajiban yang senyatanya telah ada dan berpotensi untuk tumbuh, hidup dan berkembang sesuai dengan potensi dan kekhasan daerah. ${ }^{19}$ Adapun otonomi yang bertanggung jawab adalah otonomi yang dalam penyelenggaraannya harus benar-benar sejalan dengan tujuan dan maksud pemberian otonomi, yang pada dasarnya untuk memberdayakan daerah termasuk meningkatkan kesejahteraan rakyat yang merupakan bagian utama dari tujuan nasional. ${ }^{20}$

\section{Pajak Daerah Sebagai Pendapatan Asli Daerah}

Pajak Daerah menurut Darwin adalah kontribusi wajib kepada daerah yang terutang oleh orang pribadi atau badan yang bersifat memaksa berdasarkan undang-undang, dengan tidak mendapat imbalan secara langsung dan digunakan untuk keperluan daerah sebesar-besarnya kemakmuran rakyat. ${ }^{21}$ Adapun pengertian Pajak Daerah menurut Undang-undang Nomor 28 Tahun 2009 Tentang Pajak Daerah dan Retribusi Daerah adalah kontribusi wajib kepada daerah yang terutang oleh orang pribadi atau badan yang bersifat memaksa berdasarkan undang-undang, dengan tidak mendapatkan imbalan secara langsung dan digunakan untuk keperluan daerah bagi sebesar-besarnya kemakmuran rakyat. ${ }^{22}$

Menurut Davey dalam bukunya Financing Regional Government, yang dikutip oleh Kesit Bambang Prakosa, kriteria pajak daerah terdiri dari 4 hal, yaitu: 1). Pajak yang dipungut oleh pemerintah daerah berdasarkan pengaturan dari daerah sendiri; 2). Pajak yang dipungut berdasarkan peraturan pemerintah pusat tetapi penetapan tarifnya dilakukan oleh pemerintah daerah; 3). Pajak yang ditetapkan dan atau dipungut oleh pemerintah daerah; 4). Pajak yang dipungut dan diadministrasikan oleh pemerintah pusat tetapi hasil pemungutannya diberikan kepada pemerintah daerah. ${ }^{23}$

\footnotetext{
${ }^{19}$ HAW. Widjaja, Penyelenggaraan Otonomi Daerah di Indonesia, h.133.

20 Mohammad Abul Musaad, Penguatan Otonomi Daerah "Dibalik Bayang-Bayang Ancaman Disintegrasi, h.74.

${ }^{21}$ Darwin, Pajak dan Retribusi Daerah, Cetakan pertama, (Jakarta: Mitra Wacana Media, 2010), h.100.

${ }_{22}$ Pasal 1 ayat (10) Undang-undang Nomor 28 Tahun 2009 Tentang Pajak Daerah dan Retribusi Daerah

${ }^{23}$ Kesit Bambang Prakosa, Pajak dan Retribusi Daerah, Cetakan pertama, (Yogyakarta: UII Press, 2005), h.2.
} 
Salam; Jurnal Filsafat dan Budaya Hukum - 335

Adapun jenis-jenis Pajak Daerah, yaitu : Pajak Hotel, Pajak Hiburan, Pajak Reklame, Pajak Penerangan Jalan, Pajak Mineral Bukan Logam dan Bebatuan, Pajak Parkir, Pajak Air Tanah, Pajak Sarang Burung Walet, Pajak Bumi dan Bangunan Perdesaan dan Perkotaan dan Pajak Bea Perolehan Hak atas Tanah dan Bangunan. ${ }^{24}$ Walaupun demikian, daerah kabupaten/kota dapat tidak memungut salah satu atau beberapa jenis pajak yang telah ditetapkan apabila potensi pajak di daerah kabupaten/kota tersebut dipandang kurang memadai. ${ }^{25}$

\section{Retribusi Daerah Sebagai Pendapatan Asli Daerah}

Menurut Marihot, retribusi daerah adalah pungutan daerah sebagai pembayaran atas jasa atau pemberian izin tertentu yang khusus disediakan dan atau diberikan oleh pemerintah daerah untuk kepentingan orang pribadi atau badan. $^{26}$

Menurut Undang-undang Nomor 28 Tahun 2009 Tentang Pajak Daerah dan Retribusi Daerah Retribusi Daerah, Retribusi Daerah yang selanjutnya disebut Retribusi, adalah pungutan Daerah sebagai pembayaran atas jasa atau pemberian izin tertentu yang khusus disediakan dan/atau diberikan oleh Pemerintah Daerah untuk kepentingan orang pribadi atau Badan. ${ }^{27}$

Beberapa ciri yang melekat pada retribusi daerah yang saat ini dipungut di Indonesia, adalah sebagai berikut: 1). Retribusi merupakan pungutan yang dipungut berdasarkan undang-undang dan peraturan daerah yang berkenaan; 2). Hasil penerimaan retribusi masuk ke kas pemerintah daerah; 3). Pihak yang membayar retribusi mendapatkan kontra prestasi (balas jasa) secara langsung dari pemerintah daerah atas pembayaran yang dilakukannya; 4). Retribusi terutang apabila ada jasa yang diselenggarakan oleh pemerintah daerah yang dinikmati oleh orang atau badan; 5). Sanksi yang dikenakan pada retribusi daerah adalah sanksi secara ekonomis, yaitu jika tidak membayar retribusi tidak akan memperoleh jasa yang diselenggarakan oleh pemerintah. ${ }^{28}$

Sesuai dengan Undang-Undang Nomor 28 Tahun 2009, Pasal 108 retribusi daerah dapat dibagi atas (3) golongan, yaitu:

Pertama, Retribusi Jasa Umum. Retribusi Jasa Umum adalah retribusi atas jasa yang disediakan atau diberikan oleh pemerintah daerah untuk tujuan kepentingan dan kemanfaatan umum serta dapat dinikmati oleh orang pribadi atau badan. ${ }^{29}$ Sedang jenis-jenis Retribusi Jasa Umum, yaitu; 1). Retribusi pelayanan kesehatan, 2). Retribusi pelayanan persampahan atau kebersihan, 3). Retribusi biaya cetak kartu tanda penduduk dan akta catatan sipil, 4). Retribusi pelayanan pemakaman dan pengabuan mayat, 5). Retribusi pelayanan parkir di

${ }^{24}$ Pasal 2 ayat (2) Undang-undang Nomor 28 Tahun 2009 Tentang Pajak Daerah dan Retribusi Daerah

${ }^{25}$ Darwin, Pajak dan Retribusi Daerah, h.105.

${ }^{26}$ Marihot P. Siahaan, Pajak Daerah dan Otonomi Daerah, (Jakarta: PT. Raja Grafindo Persada, 2006), h.6.

${ }^{27}$ Pasal 1 ayat (64) Undang-undang Nomor 28 Tahun 2009 Tentang Pajak Daerah dan Retribusi Daerah

${ }^{28}$ Marihot P. Siahaan, Pajak Daerah dan Otonomi Daerah, h.7.

${ }^{29}$ Marihot P. Siahaan, Pajak Daerah dan Otonomi Daerah, h.167. 
tepi jalan umum, 6). Retribusi pelayanan pasar, 7). Retribusi pengujian kendaraan bermotor, 8). Retribusi pemeriksaan alat pemadam kebakaran, 9). Retribusi penggantian biaya cetak peta, 10). Retribusi penyediaan dan atau penyedotan kakus, 11). Retribusi pengolahan limbah cair, 12). Retribusi pelayanan tera/tera ulang, 13). Retribusi pelayanan pendidikan, 14). Retribusi pengendalian menara telekomunikasi. ${ }^{30}$

Kedua, Retribusi Jasa Usaha. Retribusi Jasa Usaha adalah merupakan pelayanan yang disediakan oleh pemerintah daerah dengan menganut prinsip komersial karena pelayanan tersebut belum cukup disediakan oleh swasta. ${ }^{31}$ Sedang jenis-jenis Retribusi jasa usaha, yaitu; 1). Retribusi pemakaian kekayaan daerah; 2). Retribusi pasar grosir dan atau pertokoan; 3). Retribusi tempat pelelangan; 4). Retribusi terminal; 5). Retribusi tempat khusus parkir; 6). Retribusi tempat penginapan/pesanggrahan/villa; 7). Retribusi rumah potong hewan; 8). Retribusi pelayanan kepelabuhan; 9). Retribusi tempat rekreasi dan olahraga; 10). Retribusi penyeberangan di air; 11). Retribusi penjualan produksi usaha daerah. ${ }^{32}$

Ketiga, Retribusi Perizinan Tertentu. Fungsi perizinan dimaksudkan untuk mengadakan pembinaan pengaturan, pengendalian dan pengawasan, maka pada dasarnya pemberian izin oleh pemerintah daerah tidak harus dipungut retribusi. Akan tetapi untuk melaksanakan fungsi tersebut pemerintah daerah mungkin masih mengalami kekurangan biaya yang tidak selalu dapat dicukupi dari sumber-sumber penerimaan daerah, sehingga terhadap perizinan tertentu masih perlu dipungut retribusi. ${ }^{33}$ Sedang jenis Retribusi Perizinan Tertentu yaitu; 1). Retribusi izin mendirikan bangunan; 2). Retribusi izin tempat penjualan minuman beralkohol; 3). Retribusi izin gangguan; 4). Retribusi izin trayek; 5). Retribusi izin usaha perikanan. ${ }^{34}$

Keempat, Hasil Pengelolaan Kekayaan Daerah yang dipisahkan. Penjelasan angka (3) Undang-undang Nomor 32 Tahun 2004 Tentang Pemerintahan Daerah, yang dimaksud dengan hasil pengelolaan kekayaan daerah yang dipisahkan antara lain bagian laba dari Badan Usaha Milik Daerah, hasil kerjasama dengan pihak ketiga. Sedang dalam pasal 26 ayat (3) Peraturan Menteri Dalam Negeri Nomor 13 Tahun 2006 Tentang Pengelolaan Keuangan Daerah, ditentukan jenis pengelolaan kekayaan daerah yang dipisahkan menurut objek pendapatan yang mencakup; (1) Bagian laba atas penyertaan modal pada perusahaan milik daerah/BUMD; (2) Bagian laba atas penyertaan modal pada perusahaan milik pemerintah/BUMN; (3) Bagian laba atas penyertaan modal pada perusahaan milik swasta atau kelompok usaha masyarakat. ${ }^{35}$

${ }^{30}$ Pasal 110 ayat (1) Undang-Undang Nomor 28 Tahun 2009 Tentang Pajak Daerah dan Retribusi Daerah

${ }^{31}$ Kesit Bambang Prakosa, Pajak dan Retribusi Daerah, h.136.

${ }^{32}$ Pasal 127 Undang-undang Nomor 28 Tahun 2009 Tentang Pajak Daerah dan Retribusi Daerah

${ }_{34}^{33}$ Darwin, Pajak dan Retribusi Daerah, h.175.

${ }^{34}$ Pasal 141 Undang-Undang Nomor 28 Tahun 2009 Tentang Pajak Daerah dan Retribusi Daerah.

${ }^{35}$ Suhadak, Trilaksono Nugroho, Op. Cit., h.99. 
Salam; Jurnal Filsafat dan Budaya Hukum - 337

Kelima, Lain-lain Pendapatan Asli Daerah yang Sah. Penjelasan angka (3) Undang-undang Nomor 32 Tahun 2004 Tentang Pemerintahan Daerah angka (4) yang dimaksud dengan Lain-lain Pendapatan Asli Daerah yang Sah antara lain penerimaan daerah di luar pajak dan retribusi daerah seperti jasa giro, hasil penjualan aset daerah. Lain-lain pendapatan asli daerah yang sah, apabila dirinci menurut objek pendapatannya sebagai berikut; (1) Hasil penjualan aset daerah yang tidak dipisahkan; (2) Jasa giro; (3) Pendapatan bunga; (4) Tuntutan ganti rugi; (5) komisi; (6) Potongan; (7) Keuntungan selisih kurs; (8) Pendapatan denda atas keterlambatan pelaksanaan pekerjaan; (9) Pendapatan denda pajak dan retribusi; (10) Pendapatan hasil eksekusi atas jaminan; (11) Pendapatan atas fasilitas sosial dan fasilitas umum; (12) Pendapatan dari penyelenggaraan pendidikan dan pelatihan. $^{36}$

\section{Hasil Penelitian dan Pembahasan}

Pendapatan Asli Daerah (PAD) merupakan salah satu komponen sumber dari pembiayaan untuk penyelenggaraan pemerintahan dan mengatur rumah tangga pemerintah kabupaten Indramayu, oleh karena itu maka dalam pencapaian penerimaan pendapatan asli daerah harus optimal dan tepat waktu agar dapat memberikan kontribusi terhadap pencapaian sasaran program pembangunan dan penyelenggaraan pemerintahan serta mengatur rumah tangga pemerintah kabupaten Indramayu.

Untuk mencapai target penerimaan pendapatan asli daerah yang optimal dan tepat waktu sesuai dengan yang direncanakan, maka diperlukan upaya yang sinergis dan terintegrasi serta koordinatif oleh Dinas Pendapatan Pengelolaan Keuangan dan Aset Daerah (DPPKAD) khususnya bidang Pendapatan Asli Daerah (PAD) yang mempunyai fungsi sebagai koordinator pelaksanaan penerimaan pendapatan asli daerah dari berbagai sumber sektor penerimaan asli daerah perlu untuk mengadakan kegiatan secara terus-menerus terhadap penerimaan pendapatan asli daerah, yang terdiri dari; Pajak Daerah, Retribusi Daerah, Hasil Pengelolaan Kekayaan Daerah yang Dipisahkan, dan Lain-lain Pendapatan Asli Daerah (PAD) yang Sah.

Pelaksanaan penerimaan pendapatan asli daerah ini adalah untuk memantapkan fungsi koordinasi Dinas Pendapatan Pengelolaan Keuangan dan Aset Daerah (DPPKAD) dalam hal ini adalah bidang Pendapatan Asli Daerah (PAD) dalam menunjang pencapaian target penerimaan dari unit kerja pengelola pendapatan dalam wilayah kabupaten Indramayu, yang terdiri dari; Dinas Pendapatan Pengelolaan Keuangan dan Aset Daerah, Dinas Kependudukan dan Catatan Sipil, Rumah Sakit Umum Daerah Indramayu, Rumah Sakit Umum Daerah Sentot Patrol, Dinas Badan Penanaman Modal dan Perijinan, Dinas Perhubungan Komunikasi dan Informatika, Dinas Pemuda, Olahraga, Kebudayaan dan Pariwisata, PT. Bank Jawa Barat, Dinas Kesehatan, Dinas Kebersihan, Dinas PU Bina Marga, Dinas PU Cipta Karya, Dinas Pengelolaan Sumberdaya Air, Pertambangan dan Energi, PD. BPR/LPK, PD. Bumi

\footnotetext{
${ }^{36}$ Mahmudi, Op. Cit., h.26.
} 
Wiralodra, SPK/AKPER, Dinas Koperasi, UKM, Perindustrian dan Perdagangan, Dinas Pertanian dan Peternakan, Bagian Otonomi Desa, Dinas Kehutanan dan Perkebunan, Bagian Pertanahan, Bagian Agama dan Kesejahteraan Masyarakat, PD. Apotik Dharma Ayu, Dinas Perikanan dan Kelautan.

Ditinjau dari pendapatan asli daerah pada tahun 2010 mengalami penurunan prosentase akan tetapi kalau dilihat dari segi jumlah pendapatan penerimaannya justru jauh lebih besar di banding dengan pendapatan asli daerah pada tahun 2009. Penurunan prosentase tersebut disebabkan karena tingginya target yang ditetapkan.

Perbandingan Pendapatan Asli Daerah tahun 2009 dengan $2010^{37}$

\begin{tabular}{|l|c|c|c|c|}
\hline No & Uraian & Target & Realisasi & $\%$ \\
\hline 1 & PAD Tahun 2009 & $88.320 .473 .000,00$ & $88.412 .080 .689,33$ & 102,42 \\
\hline 2 & PAD Tahun 2010 & $104.038 .055 .056,00$ & $99.439 .222 .559,00$ & 95,98 \\
\hline
\end{tabular}

Dari tabel tersebut diatas jelaslah bahwa sekalipun penerimaan Pendapatan Asli Daerah (PAD) tahun 2010 tidak mencapai target yang direncanakan yaitu hanya $95,98 \%$ tetapi dari segi nominal penerimaan Pendapatan Asli Daerah (PAD) tersebut jauh lebih besar dibandingkan dengan penerimaan Pendapatan Asli Daerah (PAD) tahun 2009 yang mencapai target hingga $102,42 \%$.

Untuk lebih jelasnya tentang kenaikan penerimaan Pendapatan Asli Daerah pada tahun 2010, penulis paparkan Pendapatan Asli Daerah (PAD) per jenis pendapatan sebagaimana dalam tabel berikut ini:

\begin{tabular}{|c|l|r|r|}
\hline No & \multicolumn{1}{|c|}{ Jenis Pendapatan } & \multicolumn{2}{c|}{ Tahun Penerimaan } \\
\hline 1 & Pajak Daerah & $23.267 .959 .206,00$ & $25.001 .019 .406,00$ \\
\hline 2 & Retribusi Daerah & $9.043 .679 .814,00$ & $12.069 .569 .119,00$ \\
\hline 3 & $\begin{array}{l}\text { Hasil Pengelolaan } \\
\text { Kekayaan Daerah yang } \\
\text { Dipisahkan }\end{array}$ & $4.864 .423 .534,00$ & $6.572 .990 .792,00$ \\
\hline 4 & Lain-lain PAD yang Sah & $51.236 .018 .135,33$ & $55.795 .643 .242,00$ \\
\hline & & $88.412 .080 .689,33$ & $99.439 .222 .559,00$ \\
\hline
\end{tabular}

Dari uraian tersebut di atas yang penulis paparkan tentang Pendapatan Asli Daerah (PAD) kabupaten Indramayu tahun 2009 sebesar Rp. 88.412.080.689,33 (102,42\%) dari target yang ditetapkan sebesar Rp. 88.320.473.000,00 dan penerimaan Pendapatan Asli Daerah (PAD) tahun 2010 sebesar Rp. 99.439.222.559,00 (95,98\%) dari target yang ditetapkan sebesar Rp. 104.038.055.056,00 adalah merupakan potensi yang cukup besar bagi penerimaan keuangan pemerintah kabupaten Indramayu dalam meningkatkan penyelenggaraan pemerintahan dan rumah tangga pemerintah kabupaten Indramayu.

37 Dinas Pendapatan Pengelolaan Keuangan dan Aset Daerah, Realisasi Penerimaan Pendapatan Daerah kabupaten Indramayu, 31 Desember 2009 dan 31 Desember 2010. 
Salam; Jurnal Filsafat dan Budaya Hukum - 339

Penerimaan pendapatan tahun 2010 mempunyai kenaikan yang cukup signifikan yaitu sebesar Rp. 11.027.141.869,67 jika dibandingkan dengan pendapatan tahun 2009. Sekalipun penerimaan Pendapatan Asli Daerah (PAD) tahun 2010 tidak mencapai 100\% dari target yang ditetapkan, disebabkan karena target yang dinaikkan.

Dari kenaikan pendapatan tersebut sangatlah berarti bagi terselenggaranya program pembangunan pemerintah daerah kabupaten Indramayu dengan visi Indramayu Religius, Maju, Mandiri dan Sejahtera (REMAJA).

\section{Penutup}

Potensi Pendapatan Asli Daerah kabupaten Indramayu dari tahun 2009 ke 2010 mengalami peningkatan yang signifikan, yaitu sebesar Rp. 11.027.141.869,67 atau 12,47\% dari Rp. 88.412.080.689,33 pada Pendapatan Asli Daerah tahun 2009 dan Rp. 99.439.222.559,00 pada Pendapatan Asli Daerah tahun 2010. peningkatan tersebut terjadi karena keberadaan otonomi daerah. Pendapatan ini akan berpengaruh terhadap pencapaian sasaran program pembangunan dan penyelenggaraan pemerintahan daerah kabupaten Indramayu sebagai pemerintahan daerah yang otonom.

\section{Pustaka Acuan}

\section{Buku-Buku}

Abdullah, Rozali, Pelaksanaan Otonomi Luas dengan Pemilihan Kepala Daerah secara langsung, Jakarta, PT. Raja Grafindo Persada, 2005,

Abdurrahman, Beberapa Pemikiran Tentang Otonomi Daerah, Cetakan pertama, Jakarta, Media Sarana Presss, 1987.

Agus, Pramusinto dan Erwan Agus Purwanto, Reformasi Birokrasi, Kepemimpinan dan Pelayanan Publik: Kajian tentang Pelaksanaan Otonomi Daerah di Indonesia, Yogyakarta, Gava Media, 2009.

Darwin, Pajak dan Retribusi Daerah, Cetakan pertama, Jakarta, Mitra Wacana Media, 2010.

Gadjong, Agus Salim Andi, Pemerintahan Daerah “Kajian Politik dan Hukum”, Bogor, Ghalia Indonesia, 2007.

Hendratno, Edie Toet, Negara Kesatuan, Desentralisasi dan Federalisme, Cetakan pertama, Yogyakarta, Graha Ilmu, 2009.

Huda, Ni'matul, Otonomi Daerah "Filosofi, Sejarah Perkembangan dan Problematika”, Yogyakarta, Pustaka Pelajar, 2001.

Manan, Bagir, Menyongsong Fajar Otonomi Daerah, Cetakan pertama, Yogyakarta, Pusat Studi Hukum Fakultas Hukum UII, 2005.

Musa'ad, Mohammad Abul, Penguatan Otonomi Daerah "Dibalik BayangBayang Ancaman Disintegrasi, Jayapura, Universitas Cendrawasih.

Prakosa, Kesit Bambang, Pajak dan Retribusi Daerah, Cetakan pertama, Yogyakarta, UII Press, 2005. 
Sabarno, Hari, Memandu Otonomi Daerah Menjaga Kesatuan Bangsa Jakarta, Sinar Grafika, 2008.

Siahaan, Marihot P., Pajak Daerah dan Otonomi Daerah, Jakarta, P.T. Raja Grafindo Persada, 2006.

Sutedi, Adrian, Implikasi Hukum Atas Sumber Pembiayaan Daerah dalam Kerangka Otonomi Daerah, Jakarta, Sinar Grafika, 2009.

Widjaja, HAW., Penyelenggaraan Otonomi Daerah di Indonesia, Jakarta, PT Raja Grafindo Persada, 2005.

\section{Peraturan Perundang-Undangan}

Undang-Undang Dasar Negara Republik Indonesia Tahun 1945

Undang-Undang Nomor 32 Tahun 2004 Tentang Pemerintahan Daerah,

Lembaran Negara Republik Indonesia Nomor 125 Tahun 2004,

Tambahan Lembaran Negara Republik Indonesia Nomor 4437

Undang-undang Nomor 28 Tahun 2009 Tentang Pajak Daerah dan Retribusi

Daerah.

Lembaran Negara Republik Indonesia Nomor 130 Tahun 2009,

Tambahan Lembaran Negara Republik Indonesia Nomor 5049 